\title{
А.П. Петренко
}

\section{СТИЛЕВЫЕ ОСОБЕННОСТИ ФОРМИРОВАНИЯ АРХИТЕКТУРНОГО ОБЛИКА ФЕОДОСИИ В НАЧАЛЕ ХХ В.}

\begin{abstract}
В статье рассматривается архитектурное пространство Феодосии и раскрывается проблема стилеобразующих принципов формирования архитектурного облика феодосийской набережной в начале ХХ в. Анализируются стилевые особенности, проявляющиеся в архитектурных формах и художественных образах произведений искусства при оформлении экстерьеров и интерьеров феодосийских дач в эпоху модерна. Устанавливается связь основных тенденций развития русской архитектуры и прочессов, происходящих в культурной жизни города, что отразилось в архитектурном облике набережной Феодосии.

Ключевые слова: архитектура, стиль, город, семиотика, Феодосия.
\end{abstract}

За последние годы интерес к социокультурным процессам, происходящим в городском пространстве, усиливается. Интенсивная застройка и развитие городов, рост населения актуализируют ряд проблем, среди которых сохранение культурной среды города и его архитектурного наследия. Городское пространство воспринимается целостно, учитываются понимание закономерностей его развития, изменения в интерпретации образа города, которые являются общими для архитектурного пространства различных городов, однако могут носить и локальный характер. В данном контексте актуальным становится изучение стилевых особенностей формирования архитектурного облика города как условия сохранения и развития его идентичности.

Город как объект культурологического исследования представляет собой сложную семиотическую систему, совокупность текстов и кодов, принадлежащих разным языкам [1. С. 453]. Семиотический подход позволяет определить символичное пространство города как систему знаков и символов для выявления насыщенности пространства и образа города. С помощью синхронного и диахронного принципов анализа можно выявить факторы формирования архитектурного облика. Символика архитектуры в оформлении зданий и внутреннего убранства имеет огромное значение, так как архитектурные формы и детали заключают в себе характерные смыслы.

Период XIX-XX вв. представляет особый интерес для исследователей, так как характеризуется сложностью и противоречивостью многих явлений в истории и культурной жизни Российской империи. Необходимо отметить, что в это время наблюдается переход художественного процесса от академического направления к моделированию новой символико-эстетической программы. В архитектурном пространстве развивается тенденция, обусловленная смешением различных стилей.

$\mathrm{XX}$ в. был богат на стилевые направленности, осуществлявшиеся с помощью трансляции одного вида искусства языком другого. Архитектура в этот период характеризуется эклектикой - смешением архитектурных сти- 
лей минувших эпох. В архитектурном облике городов происходит трансформация пространства с использованием различных стилей в оформлении фасадов архитектурных объектов.

К началу XX в. в архитектуре крымских городов, как и в других городах страны, распространилось течение, носящее название «Модерн». Данное направление первенствовало в идейно-художественных процессах, отражая духовные и материальные потребности эпохи.

На наш взгляд, Феодосия занимает особое место среди крымских городов, так как ее культурно-историческое наследие имеет античные корни, история неразрывно связана со многими известными личностями, а трансформация городского пространства воспринимается как реакция на культурноисторические процессы, происходящие в стране.

Предметное изучение архитектурных объектов как памятников истории города дает возможность определить общероссийские тенденции развития крымской архитектуры. Однако следует отметить, что дачи, построенные на набережной Феодосии в начале ХХ в., придают городу черты индивидуальности и своеобразия.

Актуальность исследования обусловлена недостаточной изученностью темы, отсутствием в научно-исследовательских трудах анализа стилевых особенностей и разнообразных проявлений эклектики в формировании архитектурного облика Феодосии, способствующих созданию уникального образа города. Целью исследования является обоснование влияния эклектики на формирование облика набережной Феодосии, ее проявления в архитектурных образах зданий.

Как показывает изучение различных материалов, связанных с развитием города, на протяжении XIX - начала XX в. в Феодосии сформировалась особая культурная среда, элементы которой нашли воплощение в архитектуре имений фабрикантов, хлеботорговцев, помещиков и представителей творческой элиты России, возводивших особняки и загородные дачи на берегу моря по оригинальным проектам известных архитекторов. Мастера монументального и декоративно-прикладного искусства украшали интерьеры зданий деталями, относившимся к различным видам искусств. В фасадах этих зданий проявилась особая атмосфера того времени, отразились истории города и своеобразие культуры.

Е.И. Кириченко определяет особенность нового стиля модерн в архитектуре конца XIX - начала XX в. как символичность в архитектуре [2. С. 117]. М.В. Нащекина отмечает: «На архитектурные образы русского модерна существенным образом влияет мировоззрение символизма, изменив содержание архитектурной деятельности и составляющие архитектурных сооружений» [3. С. 156]. Проблеме символичности модерна в скульптуре и осмыслению его в пластике посвящены исследования К.Н. Гаврилиной. Она подчеркивает, что восточные мотивы находят свое воплощение в оформлении архитектурных зданий и пластических архитектурных образах в интерьере, а влияние идей символичности модерна заметно и в декоративно-прикладном искусстве [4. С. 239]. В исследовании Г. Земпера стиль рассматривается как способ бытия, способ понять архитектуру как симбиоз культурных составляющих - видов искусства [5. С. 320]. 
В начале XX в. характерные черты стиля модерн используются архитекторами при проектировании застройки. По мнению многих исследователей, архитектура Крыма в стилевом отношении характеризуется эклектикой, в основе которой лежат общероссийские архитектурные тенденции. Особая роль в украшении архитектурных зданий отводится декору фасадов в сочетании с объемно-пространственными решениями, что является главной отличительной чертой архитектуры начала XX в.

Своеобразие застройки набережной с особняками разнообразных архитектурных форм сформировало новый архитектурный облик города. Характерным приемом отделки фасадов является рельефная орнаментика. Орнаментальные мотивы приобретают символическую изобразительность. Однако символичный характер модерна наблюдается не только в фасадах архитектурных зданий, но и в интерьерах, формах мебели, предметах быта.

На наш взгляд, диалогический характер эклектики модерна создается на уровне стилистического соотношения фасадных композиций, где эклектика служит объединяющим фактором формирования целостности архитектуры в стиле модерн. Строительство дач на феодосийской набережной, которые, по мнению большинства исследователей, являются образцами эпохи эклектики, радикально меняет архитектурный облик города. Происходит трансформация городского пространства как динамической структуры. Композиционные приемы, которые использовались в строительстве разных эпох, служат основанием для эклектики, а различные стили становятся составляющими конструкциями визуализации фасадов.

Изученные материалы показывают, что к созданию нового архитектурного облика города были приобщены все слои общества. На Екатерининском проспекте от дома И. Айвазовского расположились дачи богатых предпринимателей, которые за короткий период сформировали новый архитектурный облик набережной Феодосии.

Необходимо отметить, что для архитектурной среды Феодосии характерными чертами являются равнозначность форм разных исторических стилей, равномерность акцентов, равноценность набора декоративных деталей на фасаде, которые соотносятся с размерами и формами оград, балконов, колонн, пилястр, оконных и дверных проемов. Н. Штольдер утверждает: «Символический характер модерна, как форма философско-художественного мышления, занимает особое место в архитектуре. Это связано с традиционностью и культурными парадигмами, историческими закономерностями и их философским осмыслением» [6. С. 35].

Согласно мнению исследователей крымской архитектуры одной из характерных построек эпохи эклектики в архитектурном облике Феодосии является дача Абрама Крыма «Отрада», созданная по проекту Н.П. Краснова. Она выполнена по образцам средневековой и испанско-мавританской архитектуры с необычными симметричными окнами, декоративными колоннами и украшена лепкой и резьбой по камню на фасаде. Для дач «Флора», «Аида», «Модерн» характерным является выразительное декорирование с использованием стилистических принципов готики, барокко, мавританского стиля.

Одним из особняков, что занимает особое место в нашем исследовании и на сегодняшний день, по мнению большинства исследователей, считается 
наикрасивейшим особняком в Крыму, является загородная дача табачного фабриканта И. Стамболи. Петербургский архитектор О.Э. Вегенер создал проект в соответствии с традициями архитектурной школы того периода в стиле модерн с доминированием мавританского стиля, идеально вписав его в окружающий ландшафт, отобразив в архитектурном облике национальные традиции народов Крыма.

Дача И. Стамболи представляет собой здание с витражами на окнах, тремя декоративными куполами, крытыми галереями и декоративным минаретом. При этом необходимо отметить, что ограда - розетки и ворота - представляет собой образец кузнечного искусства начала XX в. Вход с восточной стороны дачи украшает резной мраморный портал с растительным орнаментом. Обращает на себя внимание исследователей внутренний интерьер дачи И. Стамболи, для которого характерно использование разнообразных архитектурных стилей, несмотря на внешний мавританский облик здания. При этом необходимо отметить, что лишь на центральной лестнице просматривается смешение различных стилей: элементы барокко на стенах, центральное окно в готическом стиле, мавританский потолок, а поручни в древнерусском стиле - объединение растительного орнамента с птичьими мотивами.

По словам А.И. Коваленко, обращение к растительным мотивам было характерной чертой стиля модерн. Композиции, созданные гибкими стеблями, листьями утонченной формы, причудливыми, часто экзотическими цветами, наблюдаются в интерьере дачи. В декоративном убранстве интеръера в качестве основы растительного орнамента - листья табака и его плоды символ табачной фабрики. На перилах уникальной мраморной лестницы резной декор из красного дерева, который первоначально был покрыт позолотой. Основной тон стен интерьера - гнетущая темная готика и готические обкладки деревянных дверей. В рабочем кабинете И. Стамболи потолок, где изображение орлов с молниями символизирует защиту дома от огня, выполнен в русской архитектурной традиции, а греческий орнамент набегающей волны и камин в форме ракушки - символ приморского города. В парадном кабинете И. Стамболи, где интерьер выполнен в греческом и восточном стиле, также делается акцент на потолке с изображением цветов табака и гирлянд из табачных листьев - как символ табачного фабриканта. С вестибюля особняка, где все обшито деревом в викторианском стиле и потолок в индийском стиле, расположен выход в зимний сад, где находится фонтан со скульптурами в греческом стиле.

Необходимо отметить, что, несмотря на разнообразие мотивов и фактур, сочетание различных материалов - камня и резного дерева, черепицы, композиций из цветной поливной керамики, резьбы по мрамору, создается гармоничное архитектурно-художественное единство облика здания.

Анализ источников, посвященных архитектуре XX в., показывает, что существует и иная точка зрения на смешение стилей в архитектурных постройках Феодосии начала ХХ в. По словам А.И. Коваленко, с использованием разнообразных стилей в архитектуре расширяется диапазон стилевых разнообразий, часто не сохраняя при этом единство архитектурной формы. В этом своеобразии эклектики проявилась роскошь архитектуры начала XX в. Тем не менее исследователь сообщает, что каждый архитектор созда- 
вал неповторимость своего образца, воплощенную в деталях художественного стиля [7. С. 90].

Статья «Об искусстве Феодосии» М. Волошина, поэта, художественного критика, теоретика и историка искусства, является важным источником для комплексного изучения архитектурного облика города; его определения явлений искусства и критические оценки вошли в искусствоведческие исследования и учитывались в научных изысканиях последующих поколений. По его словам, дачи и виллы на феодосийской набережной абсолютно безвкусны, представляют собой «Музей дурного вкуса» [8. С. 126].

Действительно, в феодосийских дачах эклектизм существует так же, как и в большей части архитектурных построек в Крыму, что свидетельствует об отсутствии чистого стиля. Однако, по словам А. Пальчиковой, это не мешает им быть шедеврами архитектуры [9. С. 187]. А. Коваленко называет эклектизм «изящным, загадочным и романтичным» [10. С. 90].

Анализируя облик феодосийской набережной начала XX в., необходимо отметить, что архитектурные формы приобретают чрезвычайную насыщенность в использовании декора. Несомненно, богатство архитектурных форм и деталей на фасадах тяготеет к барокко, пластичность и скульптурность, объемный лепной декор, детализация и скульптурные барельефы характерны для античных мотивав. В интерьерах зданий - лепка с позолотой, тканое декорирование и монументальная роспись стен, резьба по дереву характерны для мавританского стиля. Однако можно утверждать, что такая насыщенность декором не разрушает гармонию их фасадов.

Исходя из вышеизложенного, необходимо сделать вывод, что пропорциональное соподчинение архитектурных элементов, стилевая гармония декора, асимметрия расположения фасадной плоскости особняков создают новый архитектурный облик феодосийской набережной. Таким образом, эклектика является главным принципом оформления интерьеров каждого из особняков Феодосии, которым присущи особенности разнообразных художественных стилей, деталей, мотивов, позаимствованных из конкретной эпохи. Несомненно, архитекторы воссоздали архитектурные формы от Античности до модерна, которые воплощаются в фасадах и интерьерах зданий.

Проведенное исследование показывает, что архитектурный стиль модерн в усадьбах Феодосии обладает особыми качествами, которые делают эти сооружения уникальными памятниками начала XX в., так как наряду с общими стилеобразующими принципами и конструктивными формами проявляются наслоения восточно-мавританской культуры, неогреческой ордерной системы, неоготической и неорусской традиций. Архитектурный облик города представляет собой смешение различных форм, стилей и направлений, что находит отражение в феодосийских дачах, которые являются культурным наследием Крыма. Архитектурные объекты имеют черты эклектики, характерные для архитектуры начала ХХ в.

В целом можно сделать вывод, что архитектурный образ дач Феодосии, оформление внутреннего убранства зданий представляют, несомненно, яркий пример архитектуры эпохи эклектики и обладают новыми особыми качествами, что делает их уникальными памятниками своего времени. Стиле- 
вые особенности фасадных композиций и архитектура феодосийской набережной представляет культурно-историческую ценность и особый интерес для дальнейшего исследования.

\section{Литература}

1. Лотман Ю.М. Семиосфера. М. : Искусство, 2000. 704 с.

2. К Кириченко Е.И. Русская архитектура 1830-1910-х годов. М. : Искусство, 1978. 395 с.

3. Нащекина М.В. Символизм в разных видах искусства // Символизм как художественное направление : взгляд из XXI века // под ред. Н.А. Хренова, И.Е. Светлова. М.: Государственный институт искусствознания. 2013. С. 156.

4. Гаврилин К.Н. Проблема архаизма в скульптуре русского символизма // Символизм как художественное направление : взгляд из XXI века / под ред. Н.А. Хренова, И.Е. Светлова. М.: Государственный институт искусствознания. 2013. С. 239.

5. Земпер Г. Практическая эстетика. М. : Искусство, 1970. С. 320.

6. Светлов И.Е. Символизм как художественное направление : взгляд из XXI века: сб. ст. / отв. ред. Н.А. Хренов, И.Е. Светлов. М. : Гос. ин-т искусствознания, 2013. 464 с.

7. Коваленко A. Проблема стиля в архитектуре Крыма // Традиції та новації у вищій архітектурно-художній освіті : Збірка наукових праць художньо-будівельного профілю України і Росії. 1999. № 2-3. С. 89-91.

8. Волошин М.А. Путник по вселенным. М. : Сов. Россия, 1990. 384 с.

9. Пальчикова А.П. Ф.Ф. Эльсон - первый архитектор южного берега Крыма // Культура народов Причерноморья. 1997. № 2. С. 185-189.

10. Коваленко А.И. Стиль модерн в архитектуре // Общероссийский информационный pecypc [Электронный pecypc]. URL: http://pandia.ru/text/77/148/3635.php/ (дата обращения: 10.11.2016).

11. Асеев Ю.С. Архитектура Крыма. Киев : Гос. изд-во лит. по строителсьтву и архитектуре УССР, 1961.239 с.

Petrenko Anastasia P. Tavrida National Academia of Crimean Federal University named after V.I. Vernadsky (Simferopol, Russian Federation).

E-mail: petrenko.ap@mail.ru

Tomsk State University Journal of Cultural Studies and Art History, 2017. № 27. 57-63 pp. DOI: $10.17223 / 22220836 / 27 / 6$

STYLISTIC PECULIARITIES OF FORMATION OF THE ARCHITECTURAL APPEARANCE OF FEODOSIA IN THE EARLY TWENTIETH CENTURY

Key words: architecture, style, town, semiotics, Feodosia.

In recent years the interest to socio-cultural processes is taking place in urban space, is growing and draws attention of different thinkers. Intensive building and urban development, the growth of population update a number of issues: preserving of cultural urban environment and it's architectural heritage. The urban space is perceived in a holistic manner, patterns of it's development are taken into account too, changing the interpretation of the lifestyle of the city, which are general for architectural space of different cities, however they can have a local character. In this context relevant today the study of peculiar features formation of architectural image of the city. As conditions of preserving and developing it's identity.

In this study the problem is of interaction different directions and principles of forming architectural of Feodosia boardwalk in the early XX century. The analysis is carried out style peculiarities are occurred in architectural shapes and art images of masterpieces. In the issuance of exteriors and interiors of Feodosia dachas in the age of eclecticism. There is a real connection in major trends style development of Russian architecture and it's processes taking place in cultural life of the city and it is strongly depicted in architectural image of Feodosia boardwalk.

In our view, Feodosia has a special place among other Crimean cities for the study of style peculiarities and forming of architectural face. The socio-historical heritage has ancient roots, the history is incredible connected with a lot of famous people, and transformation of urban space is connected with cultural and historical processes in the country.

The special examination of monuments which reflect the history of the city gives us an opportunity to determine general Russian norms of development of Crimean architecture. 
The urgency of the subject is due to lack of awareness style peculiarities and wide variety of eclecticism during the formation of boardwalk of architectural image in Feodosia and it had contributed to the creation of the unique image of the city.

The purpose of this study is to identify peculiarities of forming architectural image of Feodosia boardwalk and to prove the identification of eclecticism to develop new image of the city and justify it's expression in architectural shapes and artistic image of the buildings.

According to many researchers, the architecture of Crimea in style ratio is characterized by stylistic eclecticism, which is based on nationwide architectural trends. According to the researchers of the Crimean architecture, one of the characteristic buildings of the era of eclecticism in the architecture of Feodosia is the dacha of Abram the Crimea «Otrada is built by the project of N.P. Krasnov is implemented by samples of medieval and Spanish-Moorish architecture with unusual symmetrical windows, decorative columns and decorated with moulding and stone carving on the façade. Summer houses as «Flora», «Aida», «Modern» are characterized by expressive domain of the decoration with the stylistic principles of Gothic, Baroque, Moorish style. One of the houses that has a special place in our study, and today is country-cottage of tobacco manufacturer I. Stamboli.

The study shows that the architectural shape of the city represents a mixture of different shapes, styles and trends that are reflected in Feodosia summer houses. Architectural objects have the traits of eclecticism, typical of the architecture of the early twentieth century.

\section{References}

1. Lotman, Yu.M. (2000) Semiosfera [Semiosphere]. Moscow: Iskusstvo.

2. Kirichenko, E.I. (1978) Russkaya arkhitektura 1830-1910-kh godov [Russian Architecture of the 1830s-1910s]. Moscow: Iskusstvo.

3. Nashchekina, M.V. (2013) Simvolizm v raznykh vidakh iskusstva [Symbolism in various arts]. In: Khrenov, N.A. \& Svetlov, I.E. (eds) Simvolizm kak khudozhestvennoe napravlenie: vzglyad iz XXI veka [Symbolism as an Artistic Direction: A view from the 21st century]. Moscow: The State Institute of Art Studies. pp. 156.

4. Gavrilin, K.N. (2013) Problema arkhaizma v skul'pture russkogo simvolizma [The problem of archaism in the sculpture of Russian symbolism]. In: Khrenov, N.A. \& Svetlov, I.E. (eds) Simvolizm kak khudozhestvennoe napravlenie: vzglyad iz XXI veka [Symbolism as an Artistic Direction: A view from the 21st century]. Moscow: The State Institute of Art Studies. pp. 239.

5. Zemper, G. (1970) Prakticheskaya estetika [Practical Aesthetics]. Translated from German by V.G. Kalish. Moscow: Iskusstvo.

6. Svetlov, I.E. (2013) Al'ternativy i sintezy simvolizma (metaforicheskie smysly nagoty i kostyumirovki figury cheloveka $\mathrm{v}$ simvolistskoy zhivopisi) [Alternatives and syntheses of symbolism (metaphorical meanings of nudity and costume of a figure of a person in symbolist painting)]. In: Khrenov, N.A. \& Svetlov, I.E. (eds) Simvolizm kak khudozhestvennoe napravlenie: vzglyad iz XXI veka [Symbolism as an Artistic Direction: A view from the 21st century]. Moscow: The State Institute of Art Studies.

7. Kovalenko, A. (1999) Problema stilya v arkhitekture Kryma [The problem of style in the architecture of the Crimea]. Traditsii ta novatsiï u vishchiy arkhitekturno-khudozhniy osviti. 2-3. pp. 89-91.

8. Voloshin, M.A. (1990) Putnik po vselennym [A Traveler in the Universes]. Moscow: Sovetskaya Rossiya.

9. Palchikova, A.P. (1997) F.F. El'son - pervyy arkhitektor yuzhnogo berega Kryma [F.F. Elson - the first architect of the Southern Crimea]. Kul'tura narodov Prichernomor'ya. 2. pp. 185-189.

10. Kovalenko, A.I. (n.d.) Stil' modern v arkhitekture [Art Nouveau in architecture]. [Online] Available from: http://pandia.ru/text/77/148/3635.php/. (Accessed: 10th November 2016).

11. Aseev, Yu.S. (1961) Arkhitektura Kryma [Architecture of the Crimea]. Kyiv: Gos. izd-vo lit. po stroitels'tvu i arkhitekture USSR. 